\title{
The Victims' Court? An Analysis of the Participation of Victims of Sexual Violence in International Criminal Proceedings
}

\author{
Veena Suresh ${ }^{*}$ \\ DOI: $10.21827 /$ GroJIL.8.2.244-269 \\ Keywords \\ INTERNATIONAL CRIMINAL LAW; THE INTERNATIONAL CRIMINAL COURT; \\ SEXUAL VIOLENCE
}

\begin{abstract}
The inclusion of a victim participation scheme within the framework of the ICC is revolutionary under the domain of International Criminal Law. The scheme grants unprecedented rights for victims to participate in proceedings outside of witness capacity, as provided for at the ad hoc tribunals. This article aims to critically evaluate the ICC's victim participation scheme for victims of sexual violence. It will do so by investigating the participation scheme to establish whether it embodies inherent limits, and, if so, to assess the impact of these limitations on victims of sexual violence.

While the inclusion of a participation scheme for victims is commendable, this paper finds that there is still a long way to go before victims of sexual violence have access to a form of participation that is meaningful, in that it encompasses the participation envisaged in the provisions of the Rome Statute and considers victims' needs and expectations. This article argues that several institutional and procedural changes are required before victims of sexual violence are adequately served by the participation scheme. Lessons learnt from practice include the need for a harmonised participation procedure, providing victims of sexual violence with an influence on the charges brought against an accused, assigning collective legal representation based on crimes suffered, and encouraging resource allocation into investigating sexual crimes and non-judicial programmes that will benefit victims of sexual violence that are unable to access participatory and reparatory rights.
\end{abstract}

\section{Introduction}

Sexual violence has historically played a major role in wartime - so much so, that customary international law specifically prohibits rape and other forms of sexual violence in situations of armed conflict. ${ }^{1}$ Within the international sphere, the prosecution of sexual violence - perpetrated in peacetime and/or wartime - relies on international humanitarian law, international criminal law, and its categorisation as a war crime, genocidal act, or crime against humanity. ${ }^{2}$ This is a fairly recent development as sexual violence, and other international crimes, remained undefined until decisions of the International Criminal Tribunal for the Former Yugoslavia (ICTY) and International Criminal Tribunal for Rwanda (ICTR).

\footnotetext{
Double LLM Graduate in International Human Rights Law and Global Criminal Law, University of Groningen (veenasuri@gmail.com). The author would like to thank Prof. Dr. Caroline Fournet for her comments and feedback.

1 Kirsten Campbell, 'The Gender of Transitional Justice: Sexual Violence and the International Criminal Tribunal for the Former Yugoslavia' (2007) 1 The International Journal of Transitional Justice 411, 413.

2 ibid 414-415.

This work is licensed under the Creative Commons Attribution-NonCommercial-NoDerivatives 4.0 International License. To view a copy of this license, visit http://creativecommons.org/licenses/by-nc-nd/4.0/.
} 
Sexual violence has been recognised as an instrument of genocide, as a crime against humanity, and as torture, ${ }^{3}$ a recognition which indicates its grave nature. ${ }^{4}$ Despite the prevalence of sexual violence, it was not until recently that victims of these crimes, and other international crimes more broadly, were taken seriously in criminal proceedings. In many instances, the only provisions in place to allow their voices to be heard was through a grant of witness status, where they would be called to Court to testify against their alleged attackers. This led to discussions in which victims were characterised as the forgotten party in the criminal justice system. ${ }^{5}$ It has been well acknowledged that this process often results in secondary victimisation, and the treatment of victims of sexual violence in particular has been criticised by many. ${ }^{6}$

In response, the Rome Statute adopted an approach envisaging a dual scheme for victims at the International Criminal Court (ICC), enshrining both participatory rights and access to reparations. It is the former - specifically, the ICC's victim participation scheme for victims of sexual violence - that will form the focus of this article. Thus, this article aims to investigate the ICC's victim participation scheme to establish whether it embodies inherent limits, and, if so, to assess if and how these limitations have impacted victims of sexual violence.

In light of this overarching theme, Part I will seek to outline the ICC's victim participation scheme through an analysis of the provisions governing the Rome Statute's participation scheme, to illustrate how the scheme fits within the move towards recognising restorative justice. Part II will elucidate the role of victims of sexual violence, both in the absence of a formal victim participation scheme at the ad hoc tribunals, and as provided for in the framework of the ICC, focusing on requests to amend an indictment to include sexual crimes. The aim of Part II is to explore how victims of sexual violence have participated in proceedings, comparing their participation as witnesses at the tribunals with the victim participation afforded by the ICC's scheme. This will illustrate the modalities of participation in both settings. Part II will also undertake an analysis of fair trial rights to highlight the limitations of the scheme for victims of sexual violence. Part III will contain a critical analysis of the challenges arising out of the Rome Statute's participatory system in relation to victims of sexual crimes, and will seek to explore both the practical limitations of the scheme and how these limits constitute a barrier to a meaningful participation scheme for victims of sexual violence. The conclusion shall aim to propose recommendations on how the participation scheme can be improved to better benefit victims of sexual violence.

3 Kelly D Askin, 'Prosecuting Wartime Rape and Other Gender-Related Crimes under International Law: Extraordinary Advances, Enduring Obstacles' (2003) 21 Berkeley Journal of International Law 288, 288.

4 Doris E Buss, 'Rethinking 'Rape as a Weapon of War' (2009) 17 Feminist Legal Studies 145, 147.

5 Jo-Anne Wemmers, 'Where Do They Belong? Giving Victims a Place in the Criminal Justice Process' (2009) 20 Criminal Law Forum 395, 395.

6 See for example Susana SaCouto, 'Victim Participation at the International Criminal Court and the Extraordinary Chambers in the Courts of Cambodia: A Feminist Project' (2012) 18 Michigan Journal of Gender and Law 297; Mariana Pena, 'Victim Participation at the International Criminal Court: Achievements Made and Challenges Lying Ahead' (2009) 16 ILSA Journal of International and Comparative Law 497. 


\section{Victim Participation and the Role of International Criminal Justice}

\section{A. The ICC's Victim Participation Scheme}

Provisions governing the ICC's victim participation scheme are contained in the Rome Statute and ICC Rules of Procedure and Evidence (RPE). ${ }^{7}$ A victims' right to participate in proceedings is determined in two stages: a confirmation of victim status pursuant to Rule 85 of the RPE, followed by the provision of participatory rights, according to Article 68(3) of the Rome Statute. It is the Pre-Trial Chamber (PTC) hearing the case of the underlying acts relevant to the victim's claim that grants or denies victim status. In determining who is a victim for the purposes of participation in proceedings, the PTC makes a case-by-case assessment based on the Rome Statute provisions and the ICC's RPE. ${ }^{8}$

\section{i. Who is a victim?}

Victims are defined by Rule 85 of the ICC Rules as "natural persons who have suffered harm as a result of the commission of any crime within the jurisdiction of the Court [...]". ${ }^{9}$ Individuals claiming victim status must first file a written application with the Victim Participation and Reparations Section (VPRS) at the Registry while the relevant case is heard before the PTC. This application is sent on to the PTC overseeing the case, which decides whether to grant or deny victim status using a flexible analysis. ${ }^{10}$ Considering the succinctness of Rule 85 and Article 68 of the Rome Statute, the Court is given little guidance on their application, resulting in the acceptance of most victim applications so long as they conform with four basic criteria. ${ }^{11}$

Firstly, the PTC must assess whether the applicant is a natural person, which requires verification of identity. This verification is approached pragmatically, and the Court has held that the absence of identification documentation is insufficient to dismiss an application. ${ }^{12}$ Secondly, the PTC must determine if the facts contained in the application for participation fall within the Court's jurisdiction based on whether the alleged crime is included in the Rome Statute, was committed after 1 July 2002, and whether it occurred in the territory or was committed by a national of a State Party to the Rome Statute. ${ }^{13}$ Thirdly, the PTC must decide if the victim has suffered harm of a material,

7 Rome Statute of the International Criminal Court (adopted 17 July 1998, entered into force 1 July 2002) 2187 UNTS 90 (Rome Statute), art 68; International Criminal Court, Rules of Procedure and Evidence, ICC-PIOS-LT-03-004/19_Eng (ICC RPE), r 85.

8 Christodoulos Kaoutzanis, 'Two Birds with One Stone: How the Use of the Class Action Device for Victim Participation in the International Criminal Court Can Improve Both the Fight Against Impunity and Victim Participation' (2011) 17 UC Davis Journal of International Law and Policy 111, 122.

9 International Criminal Court, Rules of Procedure and Evidence, ICC-PIOS-LT-03-004/19_Eng (ICC RPE), r 86.

10 Kaoutzanis (n 8) 119.

11 ICC, Situation in Uganda (Prosecutor v. Kony, Otti, Odhiambo and Ongwen), Decision on Victims' Applications for Participation a/0010/06, a/0064/06 to a/0070/06, a/0081/06, a/0082/06, a/0084/06 to a/0089/06, a/0091/06 to a/0097/06, a/0099/06, a/0100/06, a/0102/06 to a/0104/06, a/0111/06, a/0113/06 to a/0117/06, a/0120/06, a/0121/06 and a/0123/06 to a/0127/06, ICC-02/04 (14 March 2008) para 8.

12 ibid para 193.

13 Kaoutzanis (n 8) 121. 
physical, or psychological nature. This too has been subject to broad interpretation. ${ }^{14}$ Finally, causality is considered: whether there is a reasonable basis to believe that the harm caused was a result of the alleged crime as being presented by the Prosecutor. ${ }^{15}$ Considering the difficulty of proving this requirement, the Court has held that causality was satisfied if "the special and temporal circumstances surrounding the appearance of the harm and the occurrence of the incident seem to overlap, or at least appear compatible rather than clearly inconsistent". ${ }^{16}$ While assessing causality is logical in determining the validity of an individual's application, in practice, victims of sexual violence remain disadvantaged, as charges of sexual violence are particularly vulnerable and can be easily dismissed, if brought at all by the Prosecutor. ${ }^{17}$ The victim's application is assessed against these criteria flexibly - if any of the four are not met, the PTC usually requests additional information, and only rarely denies the application. ${ }^{18}$

\section{ii. Who can participate?}

Perhaps the most critical provision within the Rome Statute regarding victim participation at the ICC is Article 68 (3), which reads:

"Where the personal interests of the victims are affected, the Court shall permit their views and concerns to be presented and considered at stages of the proceedings determined to be appropriate by the Court and in a manner which is not prejudicial to or inconsistent with the rights of the accused and a fair and impartial trial. Such views and concerns may be presented by the legal representatives of the victims where the Court considers it appropriate, in accordance with the Rules of Procedure and Evidence" (emphasis added). ${ }^{19}$

This provision has been described as "frustratingly vague" by scholars. ${ }^{20}$ The terms "views and concerns", "personal interests", and "proceedings" remain undefined in the Statute. The obscurity of Article 68 allows flexibility in its interpretation, ultimately leaving decisions on victim participation up to the Court. While Article 68 provides the Court with wide discretionary powers on participation, its lack of direction and ambiguity has created conflict amongst parties as to how and when victims should be allowed to participate. ${ }^{21}$ Representatives of victims have pushed for a broad interpretation of Article 68, often opposed by the Prosecution and Defence. ${ }^{22}$ The Court has largely sided with victims and their representatives by utilising a broad interpretation of the provision to allow the participation of victims in most proceedings. ${ }^{23}$

14 ibid.

15 ibid 122.

16 ICC, Prosecutor v. Jean-Pierre Bemba Gombo, Fourth Decision on Victim Participation, ICC-01/05-01/08 (12 December 2008) para 75.

17 The vulnerability of sexual charges and the link between charges brought and victim status are analysed in the following sections.

18 Kaoutzanis (n 8) 122.

19 Rome Statute, art 68(3).

20 Charles P Trumbull IV, 'The Victims of Victim Participation in International Criminal Proceedings' (2008) Michigan Journal of International Law 777, 793; Michael J Kelly, 'The Status of Victims Under the Rome Statue of the International Criminal Court' in Thorsten Bonacker, Christoph Safferling (eds) Victims of International Crimes: An Interdisciplinary Discourse (Asser Press Springer 2013) 53.

21 Kelly (n 20) 53.

22 Trumbull (n 20) 794.

23 Kelly (n 20) 53. 


\section{iii. What does participation entail?}

The content of the right to participate has been interpreted by the Court, as the Statute and Rules of Procedure and Evidence say very little on its practical operation. Victims generally have access to the public record of the case, and the Chambers have noted that parties are permitted to notify the victim's legal representatives should certain confidential information affect victims' personal interests. Additionally, the legal representatives are entitled to identify confidential information relevant to a victims' personal interests and request authorisation from the Chambers to access it. ${ }^{24}$

Rule 91(3) of the Rules of Procedure and Evidence recognises the right to question witnesses. Victims that remain anonymous for security reasons are prevented from exercising this right to protect the rights of the accused, but those who have disclosed their identities may request permission from the Chamber to do so by presenting witness statements on how the accused's actions affect the victims' personal interests. ${ }^{25}$ It is also often required that the legal representatives file questions they wish to pose before questioning begins. This means that timely access to the case records is important so that the representatives are aware of when they must request to intervene. ${ }^{26}$ Victims have also been granted rights to challenge and submit evidence. ${ }^{27}$

\section{B. The Move Towards Restorative Justice and Why It Matters}

In their 2013 report on the revised strategy in relation to victims, the ICC Assembly of the States Parties claimed "the Court was created with both a punitive and restorative function, with the Rome Statute granting victims a right to directly participate in proceedings". ${ }^{28}$ While the punishment of perpetrators creates conditions for justice in a retributive sense, restorative justice focuses on involving all those with a stake in an offence by addressing harms, needs, and obligations to put things right as far as possible. ${ }^{29}$ Restorative justice focuses on the idea that justice is a process, and not just a judgment, and thus, must allow redress for victims' suffering. ${ }^{30}$ As such, active victim participation is central to restorative justice as it provides victims with the opportunities to have their voices heard. ${ }^{31}$ Through incorporating these provisions in the Rome Statute, the drafters instilled upon the Court the challenge of balancing justice's restorative and retributive functions.

The Lubanga case, as the first case to come to judgment at the ICC and the first to take into account this issue, exemplified the provisions included in the Rome Statute on victim participation. In their opening statements, victim participants stated the purpose of

24 ICC, Situation in the Democratic Republic of the Congo (Prosecutor v. Lubanga Dyilo), Decision on Victims' Participation, ICC-01/04-01/06-1119 (18 January 2008) paras 105-107.

25 Pena (n 6) 505.

26 Lubanga, Decision on Victims' Participation (n 24) para 107.

27 ibid paras 108-111.

28 Assembly of States Parties, International Criminal Court, 'Report of the Court on the Implementation in 2013 of the Revised Strategy in Relation to Victims', ICC-ASP/12/41 (11 October 2013) para 28.

29 Donald H J Hermann, 'Restorative Justice and Retributive Justice: An Opportunity for Cooperation or an Occasion for Conflict in the Search for Justice' (2017) 16 Seattle Journal for Social Justice 71, 72.

30 Mariana Pena and Gaelle Carayon, 'Is the ICC Making the Most of Victim Participation' (2013) 7 The International Journal of Transitional Justice 518, 522.

31 Claire Garbett, 'The International Criminal Court and Restorative Justice: Victims, Participation and the Processes of Justice' (2017) 5 Restorative Justice: An International Criminal Journal 198, 200; Claire Garbett, 'The Truth and the Trial: Victim Participation, Restorative Justice, and the International Criminal Court' (2013) 16 Contemporary Justice Review 193, 194. 
their participation as an opportunity to "elucidate the truth on what happened and all the truth", ${ }^{32}$ where they noted that sharing their experiences contributed to "shedding light on what actually happened, and to fill the gap that could take place between procedural establishment of facts and the truth itself". ${ }^{33}$ As such, the victims' interests in the search for the truth has been emphasised by the Chambers, which confirmed that Court proceedings are capable of satisfying that interest. ${ }^{34}$ The participation scheme, thus, aligns itself with the Court's overall obligation to "establish the truth", 35 exhibiting the importance of the inclusion of victims in the process of justice.

Scholars and civil society organisations have identified numerous benefits to allowing victim participation in international criminal proceedings. ${ }^{36}$ Above all, offering a voice to those most affected enhances the process of international criminal justice. ${ }^{37}$ As UN Secretary General Kofi Annan emphasised at the opening of the Rome Conference, the 'overriding interests must be that of the victims and the international community as a whole'. ${ }^{38}$ The Rome Statute's inclusion of participatory rights for victims affirms this notion and represents a global shift towards recognising restorative justice.

\section{Where Do Victims of Sexual Violence Stand? The Role of Victims in the International Prosecution of Sexual Violence}

\section{A. Victims of Sexual Violence Participating in Akayesu: the Role of Victims in the Historic Genocidal Rape Judgment at the ICTR}

Although the framework of the ad hoc tribunals does not include a victim participation scheme, victims have still had influence on proceedings. In the absence of a participation scheme, victims can participate in a witness capacity by testifying. For a victim to be called before a tribunal, they must be called as a witness by either party, or by the Chambers acting proprio motu. ${ }^{39}$ Most victim-witnesses are called to testify for the prosecution.

Victims have had a major role in their witness capacity by influencing the inclusion of sexual violence charges on the indictment. On multiple occasions, the Office of the Prosecutor (OTP) has applied for leave to amend the indictment to include charges of sexual violence in response to victim-witness testimony. Although not isolated instances, the tribunals have been reluctant to allow amendments to include uncharged sexual

32 ICC, Prosecutor v. Thomas Lubanga Dyilo, Transcript, ICC-01/04-01/06 (30 October 2007), 23; Garbett (2017) (n 31) 200; Garbett (2013) (n 31) 194.

33 ICC, Prosecutor v. Thomas Lubanga Dyilo, Transcript, ICC-01/04-01/06 (26 January 2009), 41; Garbett (2017) (n 31) 200; Garbett (2013) (n 31) 194.

34 ICC, Prosecutor v. Katanga/Ngudjolo, Decision on the Set of Procedural Rights Attached to Procedural Status of Victim at the Pre-Trial Stage of the Case, ICC-01/04-01/07-474 (13 May 2008) paras 31-36.

35 Lubanga, Decision on Victims' Participation (n 24) para 133.

36 For more on these benefits, see e.g. Carsten Stahn, Hector Olasolo, Kate Gibson, 'Participation of Victims in Pre-Trial Proceedings of the ICC' (2006) 4 Journal of International Criminal Justice 219, 221; Pena (n 6) 500; Luke Moffett, 'Meaningful and Effective? Considering Victims' Interests Through Participation at the International Criminal Court' (2015) 26 Criminal Law Forum 255, 258.

37 Pena and Carayon (n 16) 527.

38 United Nations, 'UN Secretary-General declares overriding interest of international criminal court conference must be that of victims and world community as a whole', Press Release SG/SM/6597 (15 June 1998).

39 International Criminal Tribunal for the Former Yugoslavia, Rules of Procedure and Evidence (adopted 11 February 1994, as amended 8 July 2015) IT/32/Rev.50 (ICTY RPE), r 89; International Criminal Tribunal for Rwanda, Rules of Procedure and Evidence (adopted 29 June 1995, as amended 13 May 2015) (ICTR RPE), r 89. 
offences or additional facts, particularly near or during the trial, due to concerns related to the fair trial rights of the accused in combination with the need for expediency. ${ }^{40}$

The Akayesu case was acclaimed as "the most important decision rendered thus far in the history of women's jurisprudence", ${ }^{41}$ due to its rulings on rape as genocide. While this remark was published twenty years ago, it is largely still valid today. In Akayesu, the Tribunal recognised rape as a crime against humanity, a war crime, and as part of an intent to perpetrate genocide against the Tutsi population of Rwanda. In this case, the Trial Chamber (TC) found that acts of sexual violence, such as rape, constitute the actus reus for genocide as they cause "serious bodily or mental harm to members of the group" ${ }^{42}$ It added that rape perpetrated with the intent to destroy could constitute genocide, disencumbering it from a pre-existing category of genocidal acts. Scholars lauded this judgment as a "step in the direction of ending impunity for sexual violence on the supranational criminal level". ${ }^{43}$

The original indictment against Jean-Paul Akayesu, however, did not include any charges of sexual violence. At the end of the Prosecution's case in 1997, multiple witnesses testified to witnessing or experiencing sexual violence in the Taba commune, where Akayesu was mayor. Eighteen days into the trial, Witness J testified that her daughter had been gang-raped during the genocide and that she had not been previously questioned in relation to this incident. ${ }^{44}$ Witness $\mathrm{H}$ further testified that she had been raped after being chased by members of the Hutu militia; after fleeing to the commune office to seek refuge, she testified to witnessing the rape of many other women and girls. ${ }^{45}$ The judges questioned the women on their experiences of sexual violence during the genocide and ensured that their experiences would be part of the trial record. ${ }^{46}$ Judge Pillay stayed proceedings and ordered the Prosecutor to conduct further investigation. ${ }^{47}$

The testimonies of Witnesses $\mathrm{J}$ and $\mathrm{H}$, as well as reports on the prevalence of sexual violence during the genocide, led to the filing of an amicus curiae brief by the Coalition for Women's Human Rights in Conflict Situations, urging the Chamber to push for the inclusion of sexual violence charges. The brief cited the mention of sexual violence in the Prosecution's opening statements alongside various reports documenting rape and sexual violence in Rwanda, and asserted that the Prosecution's failure to bring charges of sexual violence raised "questions about the commitment of the Tribunal to the elimination of

40 Patricia Wildermuth and Petra Kneuer, 'Addressing the Challenges to Prosecution of Sexual Violence Crimes before International Tribunals and Courts' in Morten Bergsmo, Alf Butenschøn Skre, Elisabeth J Wood (eds) Understanding and Proving International Sex Crimes (Torkel Opsahl Academic EPublisher 2012) 95.

41 Kelly Askin, 'Women's Issues in International Criminal Law: Recent Developments and the Potential Contribution of the ICC' in Dinah Shelton (ed) International Crimes, Peace, and Human Rights: The Role of the International Criminal Court (Ardsley NY: Transnational Publishers, 2000) 47.

42 ICTR Statute, art 2.

43 Anne-Marie de Brouwer, Suprantional Criminal Prosecution of Sexual Violence: The ICC and the Practice of the ICTY and ICTR (Intersentia 2005) 427.

44 Rosemary Grey and Louise Chappell, 'Gender-just judging' in international criminal courts: new direction for research' in Susan H Rimmer and Kate Ogg (eds) Research Handbook on Feminist Engagement with International Law (Edward Elgar Publishing 2019) 223.

45 ibid.

46 ibid.

47 Rhonda Copelon, 'Gender Crimes as War Crimes: Integrating Crimes Against Women into International Criminal Law' (2000) 46 McGill Law Journal 217, 225. 
gender-based violence as well as the protection and advancement of the human rights of women". 48

The Prosecution then requested leave to amend the indictment, pursuant to the procedure enshrined in Rule $50 \mathrm{RPE}$, by adding charges of sexual violence, a request that was allowed by the TC. ${ }^{49}$ The contributions made by witnesses such as $\mathrm{J}, \mathrm{H}$ and many others had a profound impact on the prosecution of sexual violence; the amended indictment included charges of sexual violence and put in place the groundwork necessary for the TC to come to its landmark judgment on genocidal rape. This did not remain an isolated instance. A similar situation arose in the Musema case, where the Prosecutor requested leave to amend the indictment to include a rape charge, citing the precedent set in Akayesu, which was allowed by the Chamber. ${ }^{50}$

The Rule 50 procedure allowing for amendment of indictments acts as an important safeguard to allow for the addition of sexual violence charges once proceedings have commenced. This procedure is imperative to avoid impunity for perpetrators of sexual crimes as evidence of sexual violence often arises in the course of proceedings. ${ }^{51}$ It is equally important with regards to the role of victims in proceedings, as it is victim-witness testimony that has often motivated the Chambers and Prosecutor to request an amendment of an indictment to include additional charges.

On the flip side, amending an indictment to include additional charges has the potential to prejudice the rights of the accused, such as the right to be tried without undue delay, protected by Rule 50 which provides "the Prosecutor may amend an indictment, without leave, at any time before its confirmation, but thereafter only with leave of the Judge who confirmed it or, if at trial, with leave of the Trial Chamber". ${ }^{52}$ In accordance with this rule, the TC granted leave to amend the charges against Akayesu to include sexual violence, reminding the Prosecutor to transmit the amended indictment and supporting evidence to the accused and his counsel, and postponing the resumption date of the trial. ${ }^{53}$

\section{B. Victims of Sexual Violence Participating at the ICC}

The Lubanga case, as the first case to come to judgment at the ICC, was also the first to illustrate the capacity and realities of the ICC's victim participation scheme. Thomas Lubanga Dyilo was found guilty of the war crime of enlisting and conscripting child soldiers and using them to participate in hostilities. Although Prosecutor Ocampo never brought charges of sexual violence against Lubanga, despite records and knowledge of sexual violence committed against the child soldiers, ${ }^{54}$ the efforts of victims to recharacterise the facts in an attempt to amend the indictment cannot go unmentioned.

48 Amicus Brief Respecting Amendment of the Indictment and Supplementation of the Evidence to Ensure the Prosecution of Rape and Other Sexual Violence within the Competence of the Tribunal, Coalition for Women's Human Rights in Conflict Situations (1997) $<\underline{\text { http://www.womensrightscoalition.org/site/advocacyDossiers/rwanda/Akayesu/amicusbrief_en.ph }}$ $\mathrm{p}>39$.

49 ICTR, Prosecutor v. Jean-Paul Akayesu, Amended Indictment, ICTR-96-4-I (17 June 1997); Grey and Chappell (n 93) 223.

50 ICTR, Prosecutor v. Musema, Decision on Prosecutor's Request for Leave to Amend the Indictment, 1CTR-96-13 T (18 November 1998) paras 4, 13-18.

51 This will be further discussed and analysed below.

52 RPE ICTR, r 50.

53 ICTR, Prosecutor v. Jean-Paul Akayesu, Leave to Amend Indictment, ICTR-96-4-T (17 June 1997).

54 Avocats Sans Frontières and others, 'DR Congo: ICC Charges Raise Concern' (31 July 2006) <www.hrw.org/news/2006/07/31/dr-congo-icc-charges-raise-concern> accessed 6 April 2020. 
Victim participants engaged in a widespread effort to include charges of sexual violence to the indictment. ${ }^{55}$

\section{i. Victim participants in Lubanga: when victims can participate and the limits of Rule 85}

Prior to this concerted effort, the Chamber first had to decide which victims could participate. As per Rule $85 \mathrm{RPE}$, the individual must be considered a victim to participate, followed by a determination on whether their participation is appropriate, in accordance with Article 68 (3) of the Rome Statute. Rule 85 reads that victims are "natural persons who have suffered harm as a result of the commission of any crime within the jurisdiction of the court". ${ }^{56}$ When applying Article 68(3), the Court must assess "(i) whether the individuals seeking participation are victims in the case (ii) whether they have personal interests which are affected by the issues on appeal, (iii) whether their participation is appropriate and lastly (iv) that the manner of participation is not prejudicial to or inconsistent with the rights of the accused and a fair and impartial trial". 57

While the TC initially decided that Rule 85 did not restrict the participation of victims to crimes confirmed in the charges ${ }^{58}$ the $\mathrm{AC}$ overturned this decision to the detriment of the victims of sexual violence. It affirmed the TC's view that Rule 85 did not, in itself, restrict participation to the crimes charged, but found that Rule 85 must be read in context and in accordance with its object and purpose. ${ }^{59}$ As Rule 85 is a general rule applicable at all stages of proceedings, the AC reversed the TC's decision that participation was not restricted by the charges confirmed by the PTC, and confirmed that "harm alleged by the victim and the concept of personal interests under article 68(3) of the Statute must be linked with the charges confirmed against the accused." 60

Consequently, the Chamber's restrictive reading of Rule 85 confined participation to victims linked to those charges where only victims of the crimes charged were granted participatory rights. Thus, the Prosecutor's exclusion of charges of sexual violence effectively excluded victims of sexual violence from participating in the trial, or receiving reparations. Although a disappointing decision for victims of sexual violence, this decision mitigates the risk of fair trial violations resulting from the inclusion of testimony related to uncharged crimes, as discussed above.

\section{ii. Victims' request to recharacterise the facts to include charges of sexual violence}

Lubanga was charged with conscription, enlistment, or active use of children under the age of fifteen in international and non-international armed conflicts. During the pre-trial confirmation of charges the Women's Initiatives for Gender Justice sought to attain amicus

\footnotetext{
55 Pietro Sullo, 'Lubanga Case' (April 2014) in Rüdiger Wolfrum (ed) Max Planck Encyclopaedia of Public International Law (online ed) 25.

56 ICC RPE, r 85.

57 ICC, Prosecutor v. Thomas Lubanga Dyilo, Decision on the Participation of Victims on Appeal, ICC01/01/01/-6-1453 (6 August 2008).

58 Lubanga, Decision on Victims' Participation (n 31).

59 ICC, Prosecutor v. Thomas Lubanga Dyilo, Judgment on the Appeals of the Prosecutor and the Defence against Trial Chamber's Decision on Victims' Participation of 18 January 2008, ICC-01/04-01/06-1432 (11 July 2008) para 54.

60 ibid para 65.
} 
status to push the Chamber to request an expansion of charges to include sexual violence. ${ }^{61}$ This application was unsuccessful and the charges were confirmed by the PTC - the decision to omit charges of sexual violence was highly controversial, considering the widespread availability of information recording egregious sexual violence in the Democratic Republic of Congo. ${ }^{62}$

In reaction to the Prosecutor's failure to bring charges of sexual violence against Lubanga, twenty-seven victim participants requested a variation of the legal characterisation of the facts in the case, aiming to add the additional crimes of sexual slavery and inhuman and cruel treatment to the charges pursuant to Regulation 55 of the Regulations of the Court. Regulation 55 provides that a "Chamber may change the legal characterisation of facts to accord with the crimes [...] or to accord with the form of participation of the accused [...] without exceeding the facts and circumstances described in the charges and any amendments to the charges". ${ }^{63}$

In accordance with this procedure, a majority at the TC issued a decision contemplating the possibility of amending the legal characterisation of the facts contained in the indictment, as well as those not contained but established through evidence and which were in "procedural unity" with facts pleaded. The decision cited reasons submitted by the victims' representatives: that facts and circumstances included in the charges as well as the evidence presented at trial established the material elements of sexual slavery, as well as the crimes charged. ${ }^{64}$

This decision was appealed by the Prosecution and Defence, both disputing the TC's finding that new facts and circumstances could be introduced. ${ }^{65}$ In its appeal, the Prosecution argued that continuing the procedure under Regulation 55 would require consideration of additional material, and could mean the remainder of the trial was conducted on the basis of an incorrect legal framework. ${ }^{66}$ The victims noted that they did not request a change with respect to facts not pleaded, as the new legal characterisation was consistent with the facts already pleaded in the indictment. ${ }^{67}$

61 Louise Chappell, 'Conflicting Institutions and the Search for Gender Justice at the International Criminal Court' (2014) 67 Political Research Quarterly 183, 186.

62 Sienna Merope, 'Recharacterizing the Lubanga Case: Regulation 55 and the Consequences for Gender Justice at the ICC' (2011) 22 Criminal Law Forum 311, 312.

63 International Criminal Court, Regulations of the Court, ICC-BD/01-01-04 (Regulations of the Court), reg 55.

64 ICC, Prosecutor v. Thomas Lubanga Dyilo, Decision Giving Notice to the Parties and Participants that the Legal Characterization of the Charges may be Subject to Change in Accordance with Regulation 55(2) of the Regulations of the Court, ICC-01/04-01/06-2049 (14 July 2009) paras 33-34.

65 ICC, Prosecutor v. Thomas Lubanga Dyilo, Prosecution's Document in Support of Appeal against the "Decision giving notice to the parties and participants that the legal characterization of the facts may be subject to change in accordance with Regulation 55(2) of the Regulations of the Court" and urgent request for suspensive effect) ICC-01/04-01/06 (14 September 2009) paras 3-6; ICC, Prosecutor v. Thomas Lubanga Dyilo, Defence Appeal against the Decision of 14 July 2009 entitled Decision giving notice to the parties and participants that the legal characterization of the facts may be subject to change in accordance with Regulation 55(2) of the Regulations of the Court, ICC-01/04-01/06 (10 September 2009) paras 16, 23-24.

${ }^{66}$ Lubanga, Prosecution's Document in Support of Appeal (n 65) para 20.

67 ICC, Prosecutor v. Thomas Lubanga Dyilo, Observations from the Legal Representatives of the Victims in response to the documents filed by the Prosecution and the Defence in support of their appeals against the Decision of Trial Chamber I of 14 July 2009, ICC-01/04-01/06 (23 October 2009) paras 25 - 26; ICC, Prosecutor v. Thomas Lubanga Dyilo, Judgment on the appeals of Mr Lubanga Dyilo and the Prosecutor against the Decision of Trial Chamber I of 14 July 2009 entitled "Decision giving notice to the parties and participants that the legal characterisation of the facts may be subject to change in accordance with 
The AC held that a notice of possibility of variation in the legal characterisation of facts pleaded in the indictment was fully consistent with the Rome Statute. However, after a trial has commenced, an amendment of the indictment on the Prosecution's motion is only possible in terms of the withdrawal of charges; other modifications upon the TC's own motion were not precluded. ${ }^{6}$ It found that under Regulation 55, legal recharacterisations must not exceed the facts and circumstances in the charging document and that notice on the possibility of recharacterisations must be provided to the parties. ${ }^{69}$ The AC remitted the decision on the possibility recharacterisation to the $\mathrm{TC},{ }^{70}$ which held that nothing within the facts and circumstances of the charges against Lubanga supported including sexual slavery or cruel and inhuman treatment, excluding sexual crimes in the case against Lubanga. ${ }^{71}$ In a powerful dissent to the judgment, Judge Odio-Benito stated:

"By failing to deliberately include within the legal concept of "use to participate actively in the hostilities" the sexual violence and other ill-treatment suffered by girls and boys, the Majority of the Chamber is making this critical aspect of the crime invisible. Invisibility of sexual violence in the legal concept leads to discrimination against the victims of enlistment, conscription and use who systematically suffer from this crime as an intrinsic part of the involvement with the armed group". ${ }^{72}$

Failure to include charges of sexual violence in this case was heavily criticised. ${ }^{73}$ The Chamber's ruling on recharacterisation limits victims' capacity to affect the outcome of proceedings. Indictment amendment procedures that were provided for at the ad hoc tribunals via Rule $50 \mathrm{RPE}$ allowed victims an indirect influence upon the charges on an indictment as tribunal judges could amend charges during the trial, often in response to victim-witness testimony. ${ }^{74}$ This has not been possible within the framework of the ICC, due to restrictive interpretations adopted by the Chamber in relation to Regulation 55. ${ }^{75}$ This discrepancy highlights the need for an amendment procedure within the ICC framework that provides the possibility to amend charges once evidence of sexual violence has been exposed during proceedings, as is often the case.$^{76}$ It also emphasises the need for a participatory regime that gives victims a greater say in the pursuit of justice. The recharacterisation decision demonstrates that the participation scheme is certainly limited to the extent that victims lack the ability to compel, or even influence, the Prosecutor to pursue sexual crimes, ${ }^{77}$ cutting victims of sexual violence out of proceedings if a Prosecutor

Regulation 55(2) of the Regulations of the Court", ICC-01/04-01/06 OA 15 OA 16 (8 December 2009) para 57.

68 Lubanga, Judgment on the Appeals of Mr Lubanga Dyilo and the Prosecutor on Recharaterization of the Facts (n 67) para 77.

69 ibid paras $93-100$.

70 ibid para 109.

71 ICC, Prosecutor v. Thomas Lubanga Dyilo, Decision on the Legal Representatives' Joint Submissions concerning the AC's Decision on 8 December 2009 on Regulation 55 of the Regulations of the Court, ICC-01/04-01/06 (8 January 2010) paras $34-38$.

72 ICC, Prosecutor v. Thomas Lubanga Dyilo, Separate and Dissenting Opinion of Judge Odio Benito, ICC01/04-01/06 (14 March 2012) para 16.

73 Avocats Sans Frontières and others (n 54).

74 Chappell (n 61) 188.

75 ibid.

76 Solange Mouthaan, 'The Prosecution of Gender-based Crimes at the ICC: Challenges and Opportunities' (2011) 11 International Criminal Law Review 775, 793.

77 SaCouto (n 6) 339. 
does not bring charges of sexual violence early enough. This is particularly problematic considering that evidence on sexual violence arose repeatedly during trial, but did not even have the impact of aggravating the sentence eventually imposed on Lubanga. ${ }^{78}$

Although no conviction for sexual violence was rendered, evidence of sexual violence was put on the record at trial, and acknowledged in the Lubanga judgment. ${ }^{79}$ The Chamber did not rule on sexual violence and the absence of charges meant victims could not receive reparations. While the Lubanga case provided the Chambers with the possibility to clarify the ICC's victim participation regime, it also exposed its issues. The Prosecution's failure to bring charges of sexual violence in this case and the absence of a procedure to allow amendment when evidence later arises implies that sexual crimes are such a low priority that the presentation of relevant testimony does not even suffice to allow the possibility of amendment. Another loss for victims comes in the form of the decision that victim participants must have a link to the charges brought by the Prosecutor, meaning that the Prosecutor's failure and the absence of an amendment procedure completely excludes victims of sexual violence from attaining formal participatory rights or reparations. This is even worse considering that experiences of sexual violence often arise during testimony and questioning - 15 of the 25 Prosecution witnesses mentioned sexual violence against girl child soldiers - resulting in its presence on the trial record without any possibility of justice in the form of a related conviction. ${ }^{80}$

\section{Balancing the Accused's Fair Trial Rights with the Rights of Victims}

Victim participation must be exercised "in a manner that is not prejudicial to or inconsistent with the rights of the accused and a fair and impartial trial". ${ }^{81}$ It is evident in the decisions on victim participation and recharacterising the charges that the fair trial rights of the accused are considered highly important by the Chambers. These safeguards are important to protect fair trial rights, as the provisions governing the right to participation are vague and must be interpreted by the Chambers in a balancing act between victims' rights and defendants' rights.

While the addition of a victim participation scheme within the ICC framework has been a landmark development in terms of victims' rights, in the absence of sexual violence charges, the scheme as interpreted by the Chambers in Lubanga has excluded victims of sexual violence from receiving reparations or the right to have their voices heard. Hesitancy to bring charges of sexual violence has been a recurring theme in international criminal justice for many reasons, such as lack of time and resources to investigate sexual crimes, and the Lubanga jurisprudence reveals that there is a long way to go before victims of sexual crimes can achieve participatory rights as sexual violence charges often remain, at least initially, uncharged. The Chamber's interpretation of Rule 85 as restricting participation to victims linked to the charges brought has reduced the participation scheme to little more than what was provided for within the ad hoc framework; the Chamber's decision on Regulation 55 as restricting the ability to recharacterise the facts to include sexual crimes has been detrimental to the participatory and reparatory rights of victims of sexual violence by removing their access to the aforementioned while simultaneously requiring them to

78 ICC, Prosecutor v. Thomas Lubanga Dyilo, Separate and Dissenting Opinion of Judge Odio Benito, ICC01/04-01/06 (14 March 2012) para 22.

79 ICC, Prosecutor v. Thomas Lubanga Dyilo, Trial Judgment, ICC-01/04-01/06-2842 (14 March 2012) paras $890-896$.

80 Jennifer Tridgell, 'Prosecutor v Ntaganda: The End of Impunity for Sexual Violence against Child Soldiers' (2017) 23 Australian International Law Journal 153, 154.

81 Rome Statute, art 68(3). 
still testify in relation. It is interesting that the Rule 50 procedure governing amendment of indictments at the ad hoc tribunals was, contradictorily, less restrictive and more open to the inclusion of sexual violence charges, at least early on during proceedings.

In evaluating the jurisprudence of the Chambers pertaining to the rights of the defence, the failure to recharacterise the facts to include sexual crimes in Lubanga comes down to the restrictive interpretation adopted by the Chambers. Such restrictive interpretations as adopted in, both, decisions on recharacterising the facts and on narrowing participation to victims linked with the charges brought emphasises that the Chamber values the fair trial rights of the accused. It is then curious that evidence of sexual violence was nevertheless included and acknowledged in testimony and the judgments. Allowing this testimony on the trial record has the potential to provide some recourse in the form of acknowledgement for victims of uncharged sexual crimes. However, disallowing amendments to the indictments seems to have constituted somewhat of a 'loselose' situation for both defence rights and victims' rights, in that the trial judgment acknowledged uncharged crimes, allowing the possibility for it to influence the judges' verdict, and victim participation on said uncharged crimes lacked all possibility to result in a conviction, undermining the purpose of the ICC's participatory scheme: the elucidation of the truth. ${ }^{82}$

\section{Challenges Faced and Lessons Learnt: Making Victim Participation Meaningful}

There are many barriers to the meaningful participation of victims of sexual violence in international criminal proceedings. At the outset, a definition of meaningful victim participation is required. Meaningful participation can be defined, first and foremost, as the participation intended in the Rome Statute: the actual expression of views and concerns by victims in proceedings. ${ }^{83}$ Thus, theoretical and hypothetical participatory rights do not suffice; the right to participate in proceedings must be concrete and effective, as highlighted by the Chambers. ${ }^{84}$ It is, thus, unfortunate that the ICC's victim participation scheme, as interpreted by the Judges, often falls short of a concrete and effective right to participation, as will be discussed in this section. Secondly, when defining meaningful victim participation, it is necessary to consider the expectations and needs of the victims themselves, which will be addressed later. If the ICC is to achieve meaningful victim participation that serves the communities and individuals most affected by the international crimes and gross human rights violations brought to trial, various changes are required.

\section{A. Practical Application of Procedural Rules Related to Charges and Indictments}

\section{i. Failure and hesitancy to bring charges of sexual violence results in impunity}

82 ICC, Prosecutorv. Thomas Lubanga Dyilo, Transcript, ICC-01/04-01/06 (30 October 2007) 23.

83 Christine H Chung, 'Victims' Participation at the Internatinal Criminal Court: Are Concessions of the Court Clouding the Promise?' (2008) 6 Northwestern Journal of International Human Rights 459, 509.

84 ICC, Situation in the Democratic Republic of the Congo, Decision on the Applications for Participation in the Proceedings of VPRS 1, VPRS 2, VPRS 3, VPRS 4, VPRS 5, VPRS 6, ICC-01/04-01/101-tENn-Corr (17 January 2006) para 71. 
Article 54(1)(b) of the Rome Statute requires the Prosecutor to ensure "effective investigation and prosecution of crimes within the jurisdiction of the Court" and, in doing so, to "take into account the nature of the crimes, in particular where it involves sexual violence, gender violence or violence against children". ${ }^{85}$ Despite this provision and an increased focus on sexual crimes, ${ }^{86}$ the ICC's record on the investigation of sexual crimes and bringing charges of sexual violence has been mixed. ${ }^{87}$ Failure to sufficiently investigate allegations of sexual violence resulting in a hesitancy to charge sexual crimes constitutes the first, and possibly greatest, barrier to participation of, or justice for, victims of sexual violence.

Sexual crimes are notoriously difficult to investigate, due to the private nature of sexual violence, the associated trauma victims experience, societal stigma, and a lack of physical evidence. ${ }^{88}$ These issues are augmented by the period within which investigations take place, often months or years after the offences have been committed, and the time constraints associated with trial. ${ }^{89}$ Some commentators note that the historical perception of sexual violence as a consequence of war has contributed to its perception as an opportunistic offence alongside "core" crimes, resulting in perpetrators remaining unpunished..$^{90}$ In this regard, sexual violence is often implicitly encouraged rather than committed on the basis of explicit orders, which can make it challenging for prosecutors to link high-level perpetrators with such crimes, making thorough investigations into such crimes even more important. ${ }^{91}$

The psychological and social consequences experienced by victims of international crimes cannot be understated. For victims of sexual violence, the stigma and shame associated with sexual crimes can make it even harder to come forward. It can also be very dangerous for victims to speak openly about what they have endured. As victims are often ostracised by their families and communities, bringing charges that reflect and validate their experiences can help them cope with this stigma. ${ }^{92}$ Ignoring these accounts by failing to bring the relevant charges could worsen this experience and removes the possibility of closure via justice.

As victim participation is dependent on the charges brought due to the requirement of a link between the harm they suffered and the crimes charged, Prosecutor Ocampo's failure to bring charges of sexual violence in the initial Lubanga indictment created the ripple effect of excluding victims of sexual violence from access to participation and

85 Rome Statute, art 54(1)(b).

${ }^{86}$ See art 36(8)(b) on States Parties having to take into account the need to include judges with legal expertise on specific issues, including, but not limited to, violence against women or children; See also art 44(2) on the Registrar and Prosecutor considering importance of legal expertise on violence against women in hiring staff; See also arts 43(6) and 68(1) on the VWU including staff with expertise in trauma related to sexual crimes and protective measures taking into account the nature of the crime, in particular, when it involves sexual or gender violence, respectively.

87 Susana SaCouto and Katherine Cleary, 'Importance of Effective Investigation of Sexual Violence and Gender-Based Crimes at the International Criminal Court' (2009) 17 Journal of Gender, Social Policy and the Law 339, 344.

88 Merope (n 62) 319.

89 ibid.

90 Patricia V Sellers, 'Individual(s') Liability for Collective Sexual Violence' in Karen Knop (ed) Gender and Human Rights (Oxford University Press, 2004), 190; SaCouto, Cleary (n 87) 349; K'Shaani O Smith, 'Prosecutor v Lubanga: How the International Criminal Court Failed the Women and Girls of the Congo' (2011) 54 Howard Law Journal 467, 479.

91 SaCouto and Cleary (n 87) 349.

92 K'Shaani O Smith, 'Prosecutor v Lubanga: How the International Criminal Court Failed the Women and Girls of the Congo' (2011) 54 Howard Law Journal 467, 489. 
reparations. The Prosecution cited the need for expediency when explaining the decision to pursue child soldier charges, perceived as easier to substantiate than charges of sexual violence. ${ }^{93}$ This revelation suggests that in light of investigative difficulties and time constraints, a 'streamlined' investigative strategy side-lining sexual crimes was here deemed appropriate. ${ }^{94}$ That sexual violence charges can be set aside for the sake of expediency further solidifies the inexcusable notion that sexual violence is an inevitable consequence of conflict that is not worth investigating or substantiating at trial, and contributes to the creation of an implicit hierarchy within international crimes.

It is, thus, clear that prosecutorial failure constitutes a challenge to victims of sexual violence. The Mbarushimana case is an exemplification of Prosecutor's failures pertaining to evidence. While the arrest warrant against Callixte Mbarushimana contained a wide range of sexual and gender-based crimes, including rape, torture, other inhumane acts, inhuman treatment and persecution of the basis of gender, ${ }^{95}$ not a single charge was confirmed, and he was released in 2011. In the confirmation of charges decision, the PTC criticised the Prosecution's presentation of the case, highlighting that "the charges and the statements of facts in the DCC [Document Containing the Charges] have been articulated in such vague terms that the Chamber had serious difficulties in determining, or could not determine at all, the factual ambit of a number of the charges". ${ }^{96}$ The PTC repeatedly stated that the Prosecutor did not provide enough, if any, evidence to establish substantial grounds to believe that the event in question had occurred..$^{97}$ The Prosecutor must learn from such failures by ensuring that sufficient time and resources are invested to remedy the vulnerability of charges of sexual crimes.

In 2014, signifying the culmination of two years of the ICC's second prosecutor Fatou Bensouda's effort to strengthen the OTP's focus on sexual crimes, the OTP released the Policy Paper on Sexual and Gender-Based Crimes, recognising "the challenges of, and obstacles to, the effective investigation and prosecution of sexual and gender-based crime" and committing to "integrating a gender perspective and analysis into all of its work, being innovative in the investigation and prosecution of these crimes, providing adequate training for staff, adopting a victim-responsive approach in its work, and paying special attention to staff interaction with victims and witnesses, and their families and communities". ${ }^{98}$ This paper turns out to be important to the context, considering the vulnerability of charges of sexual crimes and the difficulties in securing convictions: although fifty-seven charges of gender-based and sexual crimes in twenty cases were brought up until 2014, only twenty were confirmed, and within this period, not a single conviction for such crimes was secured. ${ }^{99}$

Two years later, in 2016, the Court finally issued its first indictment on rape as a war crime and crime against humanity in $B e m b a$, representing the change in prosecutorial

93 Chappell (n 61) 187.

94 Rita Shackel, 'International Criminal Court Prosecutions of Sexual and Gender-Based Violence: Challenges and Successes' in Rita Shackel and Lucy Fiske (eds) Rethinking Transitional Gender Justice: Transformative Approaches in Post-Conflict Settings (Palgrave Macmillan 2019) 202.

95 Prosecutorv Mbarushimana, Warrant of Arrest for Callixte Mbarushimana, ICC-01/04-01/10 (11 October 2010).

96 Prosecutor v Mbarushimana, Decision on the Confirmation of Charges, para 110.

97 ibid paras 131, 134, 169, 206, 211.

98 Office of the Prosecutor, 'Policy Paper on Sexual and Gender-Based Crimes' (ICC, June 2014), 5.

99 Valerie Oosterveld, 'The ICC Policy Paper on Sexual and Gender-Based Crimes: A Crucial Step for International Criminal Law (2018) 24 William and Mary Journal of Race, Gender, and Social Justice 443, 445-446. 
strategy and focus implemented by Prosecutor Bensouda at the OTP. ${ }^{100}$ Notwithstanding this, this case and every other charge of sexual violence laid since has subsequently resulted in acquittal, except in the recent Ntaganda judgment, pending appeal. ${ }^{101}$ Although acquittals do not necessarily indicate a failure on the part of the Court, a single conviction in relation to the number of sexual charges brought is alarming. To avoid impunity for sexual crimes, stronger safeguards must be installed to ensure that prosecutorial strategy and discretion falls in line with the overarching aims of the Rome Statute, of which the most important is to put an end to impunity. It is evident, in light of the number of acquittals and the frequency at which sexual crimes have remained uncharged due to lack of evidence, that the OTP, and the Court more broadly, must invest increased time and resources into the investigation of sexual violence. Concerted effort is required from all actors of the Court to allow victims of sexual violence to attain justice. ${ }^{102}$

\section{ii. Unclear amendment procedure for indictments and inability of victims to affect charge sheet}

Difficulties in investigating sexual crimes combined with a prosecutorial strategy that has openly prioritised prosecuting crimes other than those of a sexual character has resulted in evidence of sexual violence only emerging at trial during questioning related to other crimes, as occurred in the Lubanga trial at the ICC, but also Akayesu and Lukic at the tribunals. ${ }^{103}$ From these instances, it is clear that, in light of these failures of prosecutorial strategy, an amendment procedure allowing the introduction of sexual violence charges after the commencement of proceedings may be necessary to avoid impunity for these crimes.

A blanket provision allowing the introduction of additional charges into proceedings that have already commenced certainly has the potential to prejudice the rights of the accused. However, practice from Akayesu demonstrates that in the presence of a procedure that considers fair trial rights, such as the Rule 50 procedure governing indictment amendments at the tribunals, the addition of charges can be possible in certain circumstances and within a permitted time limit at the discretion of the TC. ${ }^{104}$ On appeal, the claim that Akayesu was prejudiced by the late indictment amendment was rejected by the AC on the grounds that the new counts fell within the spatial and temporal scope referred to in the initial indictment and more accurately reflected Akayesu's criminal responsibility. The AC also referred to the four-month adjournment period, the possibility to recall witnesses following the amendment, and the fact that no objections were raised by the Defence with regards to the new charges when Akayesu was re-arraigned to demonstrate that there had been no prejudice against the accused. ${ }^{105}$ Thus, fair trial safeguards such as granting adjournments and allowing the Defence to recall witnesses mitigated the risk of prejudicing the accused's rights without having to deny the

${ }^{100}$ Maryann E Gallagher, Deepa Prakash and Zoe Li, 'Engendering justice: women and the prosecution of sexual violence in international criminal courts' (2020) 22 International Feminist Journal of Politics 227, 229.

${ }^{101}$ Prosecutorv. Bosco Ntaganda, Judgment, Case No. ICC-01/04-02/06 (8 July 2019); Susana SaCouto, Leila N Sadat, Patricia V Sellers, 'Collective Criminality and Sexual Violence: Fixing a Failed Approach' (2020) 33 Leiden Journal of International Law 207, 210.

102 Carla Ferstman, 'Limited charges and limited judgments by the International Criminal Court - who bears the greatest responsibility?' (2012) 16 The International Journal of Human Rights 796, 807.

${ }^{103}$ Merope (n 62) 318.

${ }^{104}$ Prosecutor v. Akayesu, ICTR-96-4-T, Trial Chamber, Trial Transcript, 17 June 1997.

105 Prosecutor v. Akayesu, AC, Judgment, 1 June 2001 paras 119-123. 
amendment. In the Akayesu judgement, the TC stated that the amendment had been allowed as the "investigation and presentation of evidence related to sexual violence [was] in the interests of justice". ${ }^{106}$

Pursuant to Article 61 (7) (c) (ii) of the Rome Statute, the PTC may also invite the prosecutor to amend charges where "the evidence submitted appears to establish a different crime within the jurisdiction of the Court", as occurred in Akayesu when Judge Pillay stayed proceedings to allow the OTP to investigate further and amend the indictment. It is unfortunate that the Judges in Lubanga did not utilise this opportunity provided for by the Rome Statute to encourage the OTP to bring charges of sexual violence, to close the accountability gap. Such an invitation in the Lubanga case would have been welcome, as Prosecutor Ocampo spoke extensively on sexual violence experienced by female child soldiers at the opening of the trial, and 15 of the Prosecution's 25 witnesses testified on sexual crimes. ${ }^{107}$ In his opening statements, Prosecutor Ocampo claimed that "in this International Criminal Court, the girl soldiers will not be invisible", ${ }^{108}$ a statement that might have rung true had he not failed to investigate and charge sexual crimes.

Other than this, Regulation 55 governing the legal recharacterisation of facts is the only recourse available within the ICC framework to introduce charges of sexual violence upon emergence of evidence of these crimes at trial. As such, it contains safeguards to protect the rights of the accused; sufficient notice must be given to the defence and the TC holds discretionary powers to assess the possibility of recharacterisation against expediency and other fair trial protections. Although the AC ruled that Regulation 55 is not inconsistent with the Rome Statute, it also failed to address the broader question of whether facts can be recharacterised to a crime not originally charged, missing out on a valuable opportunity to determine the scope of the regulation.

While much of the evidence presented in the Lubanga trial is not accessible to the public, publicly available information on the sexual exploitation of female child soldiers suggests that acts of sexual violence could fall within the facts and circumstances included in the charging document. ${ }^{109}$ For instance, the Decision on the Confirmation of Charges in Lubanga states in relation to 'active participation in hostilities' that new recruits were trained in a systematic and organised fashion in that they were subjected to rigorous and strict discipline. ${ }^{110}$ The case could then be made that evidence of the use of rape as a form of discipline or punishment, as reported widely by NGOs, could fall within these facts. ${ }^{111}$ The Chamber's restrictive interpretation of Regulation 55 in Lubanga, thus, undermined the effective prosecution of crimes of sexual violence, and ignored the presence of safeguards built into the Regulation to protect the rights of the accused.

Given the unique nature of sexual crimes in terms of the social ramifications faced by the victims and evidence of sexual violence repeatedly arising at trial, interpreting Regulation 55 in narrow terms here resulted in the Chamber ignoring the experiences of sexual violence victims by disallowing the possibility of a conviction for these crimes. The safeguards within Regulation 55 to protect the rights of the accused in combination with

\footnotetext{
${ }^{106}$ Prosecutor v. Akayesu, ICTR-96-4-T, Trial Chamber, Judgment, 2 September 1998 para 417.

${ }^{107}$ Women's Initiatives for Gender Justice, Gender Report Card on the International Criminal Court 2009 $<$ http://www.iccwomen.org/news/docs/GRC09_web-2-10.pdf>, 71-85.

108 Prosecutor v Lubanga, Transcript, ICC-01/04-01/06 (26 January 2009) para 13.

109 Merope (n 62) 339-340.

${ }^{110}$ Prosecutorv. Lubanga, Decision on the Confirmation of Charges, ICC-01/04-01/06 (29 January 2007) para 265; Merope (n 62) 340.

${ }^{111}$ Merope (n 62) 340.
} 
the argument that Regulation 55 is "expressly defined in wide terms to allow the Trial Chamber flexibility in the classification of the conduct of the accused", ${ }^{112}$ suggests that a broad interpretation of Regulation 55 would indeed be consistent with the Rome Statute, and better suited to fulfil its purpose. This is especially pertinent as the AC noted itself that the purpose of the regulation was "closing accountability gaps" resultant when "legal qualifications in the pre-trial phase ... turn out to be incorrect, in particular based on evidence presented at trial", which would be "contrary to the aim of the Statute to put an end to impunity". ${ }^{113}$

As the decisions on the possibility to recharacterise the facts are to be made on a case-by-case basis by the relevant Chamber, Regulation 55 is an important recourse to ensure justice for victims of sexual violence; despite prosecutorial indifference towards sexual crimes in the Lubanga case, evidence on sexual slavery arose in those proceedings. The victims' attempt to request a re-characterisation to include sexual slavery indicated their dissatisfaction with the charges brought by the Prosecutor, and the Chamber's decision undermined the purposes and presence of a participation scheme. The decision to disallow re-characterisation, despite the presentation of evidence on sexual crimes and its mention in the opening statements of the Prosecutor, raises the question of how meaningful the participatory scheme can be for victims of sexual violence, as victims are unable to have an impact on the charges brought, arguably the most imperative factor in their access to justice.

\section{B. Practical Application of Procedural Rules Related to Victims and Participation}

\section{i. Lack of clarity in ICC's participation provisions: an inconsistent approach resulting in unequal victimhood}

Another issue pertaining to participation at the ICC is the lack of clarity in the provisions enshrining the victim participation scheme. As victim participation is not automatic and relies on the discretion of the TC, the lack of clarity present in the provisions of the Court's Statute and RPE has resulted in an inconsistent and varied approach in determining the degree and modalities of participation for each victim. ${ }^{114}$ This is best evidenced in a comparison between the systematic and piecemeal approaches adopted in the Katanga and Lubanga cases respectively. ${ }^{115}$

According to the Single Judge in Katanga, all individuals that meet the criteria of Rule 85 and who are granted victim status will always have a personal interest in participating in proceedings; thus, the determination of whether a victim's personal interests were affected was carried out on a collective basis. ${ }^{116}$ The Single Judge justified this finding by highlighting the link between guilt or innocence and the right to truth, ${ }^{117}$ emphasising that the interests of victims extend to securing punishment for those found

\footnotetext{
112 Carsten Stahn, 'Modification of the Legal Characterization of the Facts in the ICC System: A Portrayal of Regulation 55' (2005) 16 Criminal Law Forum 1, 24.

113 Prosecutor v. Lubanga (n 110) para 77.

${ }^{114}$ Solange Mouthaan, 'Victim Participation at the ICC for Victims of Gender-Based Crimes: A Conflict of Interest' (2013) 21 Cardozo Journal of International and Comparative Law 619, 628.

115 Brianne McGonigle Leyh, Procedural Justice? Victim Participation in International Criminal Proceedings (Internsentia 2011) 258-260.

116 The Prosecutor v. Katanga/Ngudjolo, No. ICC-01/04-01/07-474 (13 May 2008) para 43.

117 ibid paras 35-36.
} 
criminally responsible, ${ }^{118}$ and by extension, determined that victims have a personal interest in the outcome of the pre-trial stage, as this stage is responsible for deciding whether there is sufficient evidence providing substantial grounds to believe that the suspect is responsible for the crimes charged. ${ }^{119}$ In viewing the pre-trial stage as the broad context, the Judge determined the manner and scope for all victims in all proceedings during the pre-trial stage, building on the pre-trial case law in Lubanga and followed in Bemba. ${ }^{120}$ This approach ensures that the parties and victims' representatives are informed of the modalities of participation in advance, and can, therefore, better prepare for hearings. ${ }^{121}$

In the Lubanga case, however, the TC departed from the PTC and favoured a different approach, finding that Article 68(3) requires a determination of the specific personal interests of individual victims in relation to specific issues. ${ }^{122}$ This procedure requires that victims' legal representatives show how participation in specific trial proceedings affects the personal interests of specific victims, rather than the trial generally. ${ }^{123}$ The approach adopted by the TC in Lubanga was endorsed by the AC, ${ }^{124}$ on the basis that determining the appropriateness of participation on an individual basis sits best with the rights of the accused and the right to a fair trial. The TC in Katanga found that the recognition of victim status would automatically imply the recognition of the personal interest of the victim at the trial stage of the case, but held that it could require extra information in situations where the link between the requested intervention and the victim's personal interests were not clear. ${ }^{125}$ Thus, in the trial stage of the Katanga proceedings, a de facto piecemeal approach was adopted, where victims were indeed required to file discrete applications on how their personal interests were affected before being permitted to participate in a certain part of the trial. ${ }^{126}$

From these instances, it seems that the TCs are hesitant to provide participatory rights without having the opportunity to assess whether participation is appropriate in a particular instance, an approach that is arguably consistent with Article 68(3) and the right to a fair trial. While this may be the case, requiring the filing of a discrete written application for every instance of participation is onerous, ${ }^{127}$ and can result in delays in proceedings, as discussed in the next section.

The stark difference in each approach highlights the differences in understanding between Judges at the ICC on what victim participation entails and the modalities of participation. The lack of clarity on a uniform system governing the right to participation has resulted in victims being treated differently in different cases, and in different stages of proceedings. This inequality undermines the underlying purpose of victim participation as a "contribution to the truth-seeking justice process of the ICC". ${ }^{128}$

\footnotetext{
118 ibid para 38.

119 ibid para 43; McGonigle Leyh (n 115) 258-259.

${ }^{120}$ McGonigle Leyh (n 115) 259.

121 ibid.

122 The Prosecutor v. Lubanga, No. ICC-01/04-01/06-1119 (18 January 2008) para 97.

${ }^{123}$ McGonigle Leyh (n 115) 260.

124 The Prosecutor v. Lubanga, No. ICC-01/04-01/06-1432 (11 July 2008).

125 The Prosecutor v. Katanga/Ngudjolo, ICC-01/04-01/07-1788-tENG (22 January 2010) paras 61-62.

${ }^{126}$ McGonigle Leyh (n 115) 260-261.

127 ibid 261.

${ }^{128}$ Mouthaan (n 114) 628.
} 
Inequalities amongst victims arising from the ICC's participatory scheme are compounded by the connection between participation, reparations and the crimes charged; in this regard, victims of sexual violence are inherently disadvantaged due to the abovementioned failure to charge sexual crimes, combined with their inability to affect the charges brought. Thus, victims of uncharged crimes and those victimised outside of the locations that are subject to the charges are totally excluded, contributing to victim inequality, which may in turn negatively impact reconciliation. ${ }^{129}$ As victims of sexual crimes are so often ostracised in their own communities, the limitations of the participation scheme resulting in their removal from the judicial process can contribute to further stigmatisation.

To combat the inequalities arising from varied interpretations adopted by the Judges of the Court, a harmonised victim participation scheme is necessary. For example, by laying out the modalities of participation and leaving only the determination of exceptional rights up to Judges, such inequalities, as well as the burden on the Court, would be mitigated. ${ }^{130}$ Consistency is also equally important to manage victim expectations, so that upon application to participate, victims are duly informed of the modalities of this participation and understand its limitations.

\section{ii. Inadequate application process and common legal representation: dilution of the participatory process}

The broad definition of a victim adopted by the Chambers opens the door to innumerable applications for victim status. The Court's approach towards processing individual applications and allocating legal representation can constitute a barrier, not only to the participation of victims, but also to the right to expediency. ${ }^{131}$ While 127 victims were given permission to participate in Lubanga, this number steeply rose to 5,229 victim participants in Bemba. ${ }^{132}$ At the Assembly of States Parties on the Court's strategy towards victim participation, representatives of the Court noted an insufficiency of resources to effectively deal with the influx of applications submitted. ${ }^{133}$

In part, this is due to the long and cumbersome application process in which the VPRS receives a lengthy standard application form along with supporting evidence that must be translated into one of the working languages of the Court. Following the translation, in most cases, redactions must be made and approved by the Chamber to protect the identity of the victim, and then sent to the parties for submissions to be filed within a prescribed time limit. The Chamber must then decide, on a case-by-case basis, whether the applicant meets the Rule 85 criteria and whether their interests are affected by the proceedings. ${ }^{134}$

This approach requires that an individualised process is followed for each application. It places a particularly heavy strain on the VPRS, responsible not only for the processing of thousands of individual applications, but also for obtaining information

129 Christine van den Wyngaert, 'Victims Before International Criminal Court: Some Views and Concerns of an ICC Trial Judge' (2011) 44 Case Western Reserve Journal of International Law 475, 492.

${ }^{130}$ Luke Moffet, 'Elaborating Justice for Victims at the International Criminal Court: Beyond Rhetoric and the Hague' (2015) 13 Journal of International Criminal Justice 281, 292.

131 Susana SaCouto and Katherine Cleary Thompson, 'Regulation 55 and the Rights of the Accused at the International Criminal Court' (2014) 21 Human Rights Brief 17, 18.

132 ibid; Van den Wyngaert (n 129) 482; The Prosecutor v. Bemba Gombo, Judgment, ICC-01/05-01/08-3343 (21 March 2016) para 18.

133 SaCouto and Cleary Thompson (n 131) 20.

134 Van den Wyngaert (n 129) 481-482. 
omitted from incomplete applications and redacting sensitive information before sending the applications forward to the parties. ${ }^{135}$ The Defence has repeatedly complained that "the burden of responding to applications to participate, and the 'potentially detrimental' allegations raised therein, was impairing the Defence's preparation for the hearing", ${ }^{136}$ and that the time spent examining and making submissions on victim applications was "to the complete detriment of its capacity to investigate and prepare its own defence for the trial". ${ }^{137}$ On the impact on the Chambers, Judge Van den Wyngaert wrote that "before the start of the hearings on the merits in the Katanga case, for several months, more than one third of the Chamber's support staff was working on victims' applications". ${ }^{138}$

This process places not only a heavy burden on the organs of the Court, but results in victims themselves having to wait for a long time in between the submission of their applications and achieving recognition under Rule 85, as well as learning whether they have gained participatory rights; even in early cases with fewer applicants, victims waited up to 2 years to hear back. ${ }^{139}$ In Bemba, ongoing delays resulted in the admission of applicants at a very late stage in the proceedings by which time a significant part of the trial had unfolded. ${ }^{140}$ The resulting frustration of victims has been noted by victims' representatives, who have stated that most victims find the application procedure complicated and require assistance in completing the standardised forms. ${ }^{141}$

This frustration is compounded by the collective representation allocated for those who have obtained victim status. The organisation REDRESS in a 2012 report reviewing the practice of participation noted a 'mismatch' between victim participation and the information required from them:

Because of the individualised processing requirements, victims are requested to provide an array of personal information, including information to prove their identity, information on their experience of crimes under the jurisdiction of the Court and how they suffered harm, even though they will invariably be heard through a legal representative which represents their interests collectively with the interests of other victims also being represented. Thus, there is an apparent mismatch between the typical way in which victims will ultimately participate and the information they are required to produce in order to enable them to participate. $^{142}$

135 SaCouto and Cleary Thompson (n 131) 18.

136 Christine H Chung, 'Victims' Participation at the Internatinal Criminal Court: Are Concessions of the Court Clouding the Promise?' (2008) 6 Northwestern Journal of International Human Rights 459, 491.

${ }^{137}$ SaCouto and Cleary Thompson (n 131) 18; Prosecutor $v$ Bemba, Defence Response to the Third Transmission of Victims' Applications for Participation in the Proceedings, ICC-01/05-01/08-945 (11 October 2010) para 3; Prosecutor $v$ Bemba, Defence Observations on the Seventh Transmission to the parties and legal representatives of redacted versions of applications for participation in the proceedings, ICC -01/05-01/08-1053 (26 November 2010) para 5.

138 Van den Wyngaert (n 129) 493.

139 Mariana Pena, 'Victim Participation at the International Criminal Court: Achievements Made and Challenges Lying Ahead' (2009) 16 ILSA Journal of International and Comparative Law 497, 512.

${ }^{140}$ Mariana Pena and Gaelle Carayon, 'Is the ICC Making the Most of Victim Participation' (2013) 7 The International Journal of Transitional Justice 518, 528.

141 ibid 527.

142 REDRESS, 'The Participation of Victims in International Criminal Court Proceedings: A Review of the Practice and Consideration of Options for the Future' (REDRESS October 2012) 16. 
Victims' access to participation relies on legal representation, as no absolute statutory right of victims to participate in person exists. ${ }^{143}$ Rule 90 on the representation of victims allows choice of counsel, however, under Rule 90(3) the Court may allocate a common legal representative (CLR). As such, the appointment of CLRs to represent victims has become the standard approach adopted by the ICC; ${ }^{144}$ it has been viewed as, both, an "unavoidable necessity" to ensure effectiveness, and controversial on the basis that it negates the emphasis on choice included within Rule $90 .{ }^{145}$ Furthermore, CLRs must represent massive numbers of victims before the Court, on the basis of arbitrary groupings, such as geographical location. ${ }^{146}$ For example, in Lubanga, victims were placed into two groups on this basis with a common legal representative for each group, and the OPCV represented the group with dual status as victim and witness. ${ }^{147}$ Victim participation, defined in the Rome Statute as the presentation of views and concerns of victims, is, thus, difficult to achieve within the framework of such collective representation for victims, since victims often live considerable distances apart. While representatives must take instructions from their clients, it is challenging for these to be relayed to the Court due the sheer number of those represented. ${ }^{148}$ It is then questionable how meaningful these participatory rights are, considering that victims are very rarely actually able to have their views and concerns presented before the Court.

The focus on geography, rather than on harm suffered, has also led to criticism that collective representation may "not serve the victims' interests in relation to the high number of victims of sexual violence expected to participate". ${ }^{149}$ As such, the question of whether victims of sexual violence are adequately represented within the framework of collective representation is especially pertinent. The position of victims of sexual violence could be weakened by appointment of CLRs, due to the sensitive nature of sexual crimes. Appointing a single representative to represent large numbers of victims problematically assumes that all those applying to participate share uniform interests. Furthermore, considering the hesitancy of victims of sexual violence to speak to their CLR about these crimes in particular, besides other harms suffered, collective representation could lead to a prioritisation of other crimes over those of a sexual nature. ${ }^{150}$ Thus, arbitrary divisions of victims and grouping many victims together for the purposes of representation disregards the specificity that accompanies victimhood arising from sexual violence.

${ }^{143}$ Prosecutorv Banda, Decision on the participation of victims in the trial proceedings, ICC-02/05-03/09-545 (20 March 2014) para 20; Ruto and Sang, Decision on victims' representation and participation, ICC01/09-01/11-460 (3 October 2012) para 21.

${ }^{144}$ Prosecutor $v$ Banda and Jerbo, Order instructing the Registry to start consultations on the organisation of common legal representation, ICC-02/05-03/09-138 (21 April 2011) para 4; Anni Pues, 'AVictim's Right to a Fair Trial at the International Criminal Court? Reflections on Article 68(3)' (2015) 13 Journal of International Criminal Justice 951, 961.

145 Emily Haslam, Rod Edmunds, 'Whose Number is it Anyway? Common Legal Representation, Consultations and the 'Statistical Victim" (2017) 15 Journal of International Criminal Justice 931, 936937.

${ }^{146}$ Van den Wyngaert (n 129) 489.

147 Jean de Dieu Sikulibo, Sexual Violence and Effective Redress for Victims in Post-Conflict Situations: Emerging Research and Opportunities (IGI Global 2019) 175.

${ }^{148}$ Van den Wyngaert (n 129) 489.

${ }^{149}$ Women's Initiatives for Gender Justice, 'Statement by the Women's Initiatives for Gender Justice on the Opening of the ICC Trial of Jean-Pierre Bemba Gombo' (22 November 2010) $<$ http://www.iccwomen.org/documents/Bemba_Opening_Statement.pdf.pdf $>$.

150 Jean de Dieu Sikulibo, 'International Criminal Justice and the New Promise of Therapeutic Jurisprudence: Chelllenges in Conflict-Related Sexual Violence Cases' in Debarati Halder, K Jaishankar (eds) Therapeutic Jurisprudence and Overcoming Violence Against Women (IGI Global, 2017), 231. 
In light of the large number of applications received, the Court has tended to enact measures to preserve the expediency of proceedings, such as the imposition of strict deadlines for victim applications and the abovementioned collectivisation of the participatory process. ${ }^{151}$ Participation applications in the Kenya situation adopted a twotier approach, wherein participation through a CLR required a simple registration procedure in which eligibility was reviewed by the representative themselves for the purposes of the presentation of views and concerns without personally appearing before the Court. ${ }^{152}$ Only victims requesting to personally share their views and concerns before the Court were requested to utilise the application procedure established under Rule $89 .{ }^{153}$ This bifurcated approach significantly cuts down the burden placed on the organs of the Court in the individualised application process, as the parties, Registry and Chambers need only review the applications of victims wishing to express their views and concerns personally before the Court. While its adoption has been criticised on the point of collectivisation and removal of the individualised nature of participation, past decisions show that few participants come before the Court in person, with the bulk of victim participation taking place through the CLR. While this is a point of criticism in itself, in light of expediency requirements, utilising the two-tier approach can improve victims' experiences as it manages expectations by making clear how the victim will ultimately participate, removing the mismatch identified in the aforementioned REDRESS report that leads to victims' disappointment. ${ }^{154}$

\section{Victim Expectations and the Limits of the ICC's Participation Scheme in the Trial Process: Filling in the Gaps}

While certain limits of the participation scheme may be rectified to produce a more meaningful process for victim participants, removing all barriers to participation is impossible to reconcile with the necessities of a trial process, including the fair trial rights of the accused. The rendering of a verdict within the ICC process can, in itself, create friction - inevitably, a trial resulting in an acquittal can cause immense disappointment for victims.

Notwithstanding, it is important that the ICC takes the purposes of its participatory scheme into consideration in its decision-making processes. Victim participation has repeatedly been recognised as important for its truth-telling function; at the closing of the Lubanga trial, the OPCV representative aptly stated:

"the essential concern of the victims participating in this trial, over and beyond the conviction of the accused, is therefore to contribute to the establishment of the truth, seeking for the truth and establishing the truth". ${ }^{155}$

However, the Court has not outlined its broader perceptions of how the scheme contributes towards restorative justice: is the use of victim participation a reconciliatory measure or a means to provide healing for victims? Without elaborating the underlying goals of the participatory scheme and the types of justice that the Court cannot provide to victims, it is

\footnotetext{
151 Pues (n 144) 960.

152 ibid; SaCouto and Cleary Thompson (n 131) 20.

153 ibid.

154 SaCouto and Cleary Thompson (n 131) 20-21.

155 The Prosecutor v. Thomas Lubanga Dyilo, Trial Transcript, ICC-01/04-01/06 (25 August 2011) 62.
} 
challenging to manage victims' expectations towards their role in the ICC's justice process. ${ }^{156}$

To increase the meaningfulness of the participation scheme, the expectations of victims must be considered. While the Chambers have provided various modalities of victim participation, it has been suggested that these do not necessarily correspond with victims' needs. ${ }^{157}$ Although it is impossible to determine the needs of victims as a monolith, studies suggest that victims are often content with participation to carry an expressive function, that is, the possibility to express their views and concerns and to remain informed and duly notified of the development of their case by the ICC and their legal representatives. ${ }^{158}$ Paolina Massida argues that the majority of victims expect their story to be told by someone, other than the prosecutor, who will represent their interests in the proceedings. ${ }^{159}$ Thus, whilst the participatory scheme as it stands is a step forward for victims' rights in one respect, its other consequences, namely, victim inequalities and impunity arising from the failure to lay charges of sexual violence, combined with limited avenues to affect charges brought and the exclusion of victims of uncharged crimes, are a step backwards in the same breath.

The limits imposed on victim participation in the trial process imply that victims are still unable to narrate their stories in a way that meets their needs. Several alternatives exist to complement the limited trial process. The problems associated with the issuance of a verdict could be avoided through the use of truth and reconciliation commissions (TRCs), which do not focus on criminal prosecution, but rather work towards establishing a record of human rights violations. ${ }^{160}$ While historically these commissions have not had the best record on sexual violence, the commission set up in Sierra Leone was lauded for offering a "complex account of the social, legal, political and cultural forces that conspired to render women more vulnerable to a range of outrages and degradations". ${ }^{161}$ This demonstrates that TRCs could be considered an option to help fill in the gaps present in the Court's participation scheme - nonetheless, these commissions are often perceived as far less authoritative and condemnatory than the Court process and are vulnerable to political pressure and corruption, indicating that through solely these means, once again, a meaningful participatory process, in which victims' experiences are validated and listened to, can be challenging to achieve. ${ }^{162}$

The ICC's creation of non-judicial programmes is a worthy alternative to be considered and invested in. The Trust Fund for Victims (TFV) is responsible for reparations, but is additionally mandated to provide "physical or psychological rehabilitation or material support for the benefit of victims and their families". ${ }^{163}$ The TFV can, therefore, assist victims in countries under the Court's jurisdiction, even if they are

${ }^{156}$ Claire Garbett, 'The International Criminal Court and Restorative Justice: Victims, Participation and the Processes of Justice' (2017) 5 Restorative Justice: An International Criminal Journal 198., 209.

${ }^{157}$ Mouthaan (n 114) 630; Jo-Anne Wemmers, 'Victim Policy Transfer: Learning from Each Other' (2005) 11 European Journal of Criminal Policy and Research 121; War Crimes Research Office, 'Victim Participation at the Case Stage of Proceedings (2009).

158 Jo-Anne Wemmers, 'Victims' Rights and the International Criminal Court: Perceptions Within the Court Regarding the Victims' Right to Participation' (2010) 23 Leiden Journal of International Law 629, 643; Mouthaan (n 114) 631.

${ }^{159}$ Mouthaan (n 114) 631.

${ }^{160}$ SaCouto (n 6) 353.

${ }^{161}$ Katherine M Franke, 'Gendered Subjects of Transitional Justice' (2006) 15 Columbia Journal of Gender and Law 813, 827.

162 SaCouto (n 6) 354.

163 TFV Regulation 56. 
not connected to the specific crimes or suspects under investigation, covering a wider range of beneficiaries than the participation and reparations schemes. Thus, access to assistance is independent of the Court process and does not rely on a conviction.

In designing such programmes, the TFV actively consults with the victim population, ${ }^{164}$ and as such, these non-judicial programmes have the potential to be successful in bridging the gaps between victims' needs and the assistance they require from the Court. For instance, following the Bemba acquittal in 2018, the TFV decided to accelerate the launch of an assistance programme in the Central African Republic for both victim participants in the Bemba case, as well as victims of sexual and gender-based violence, more broadly. ${ }^{165}$ This example highlights that the TFV is aware of the importance of the creation of non-judicial programmes in response to victims' needs. However, the ICC's TFV remains underfunded and underdeveloped, with much of this external assistance funded through voluntary contributions. Encouraging resource allocation and stakeholder investment into these extra-judicial programmes could be of great benefit to the victims whom the limited participatory process is currently failing.

\section{Recommendations for Change: The Way Forward}

While the ICC's victim participation scheme is a commendable addition, it is evident that the scheme embodies limits that have negatively impacted victims of sexual violence. Considering both the procedural obstacles and the expectations of victims as outlined in the previous chapter, this conclusion will make recommendations for change so as to allow the ICC to achieve meaningful victim participation in the proceedings before it. As described earlier, meaningful victim participation encompasses a participation scheme that allows the actual presentation of victims' views and concerns as envisaged by the Statute, while considering their expectations and needs. In light of this, various recommendations are put forth below to illustrate how the ICC's participation scheme could better serve victims of sexual violence.

1. The ICC must clarify the purpose of its participation scheme. Is the scheme a reconciliatory measure, or a means for victims to have their voices heard? Setting out the rationale and goals of the participation scheme can help to manage victims' expectations.

2. As the truth-seeking function of the participation scheme has been emphasised, it is important that the scheme allows victims an opportunity to help frame the scope of the case(s) against their alleged tormentor(s). This can be achieved by allowing victim involvement at the pre-trial stage of proceedings and by adopting an amendment procedure for indictments that contains safeguards to protect the rights of the accused. Allowing the possibility of indictment amendments is particularly important in cases where evidence of sexual violence arises during proceedings, due to the nature of sexual crimes. The Court has been receptive in understanding the difficulties faced by victims of sexual violence, insofar as delayed reporting and the

164 Trust Fund for Victims, 'Report to the Assembly of States Parties on the Activities and Projects of the Board of Directors of the Trust Fund for Victims for the period 1 July 2010 to 30 June 2011', ICCASP/10/14 (1 August 2011) 5.

165 Trust Fund for Victims, 'Report to the Assembly of States Parties on the projects and the activities of the Board of Directors of the Trust Fund for Victims for the period 1 July 2017 to 30 June 2018', ICCASP/17/14 (28 July 2018) 16. 
associated stigma and shame are concerned. ${ }^{166}$ Thus, the Court could extend this understanding to instances where sexual violence evidence arises in proceedings by considering the aforementioned when deciding whether an indictment can be amended. As part of this understanding, judges could alternatively invite the Prosecution to include sex crimes charges where such evidence arises at trial.

3. All organs of the Court must invest increased financial and human resources into the investigation of sexual violence to allow meaningful participation and access to reparations for victims of sexual violence, as participation and reparations are linked to the crimes charged and convictions, respectively.

4. As collective representation is increasingly relied upon to preserve expediency, appointing representatives on the basis of the crimes victims have endured is imperative for the actual presentation of their views and concerns. In this regard, victims of sexual violence deserve to be appointed a representative that can speak to the specificities of the struggles they have faced by taking into account the societal consequences they have endured as a result of the sexual violence perpetrated against them.

5. A harmonised participation scheme must be adopted to prevent victim inequalities and the impact such inequalities could have on reconciliation within communities. Adopting a harmonised scheme would improve expediency as the Chamber would only have to assess the allowance of exceptional rights. A harmonised approach would also help to manage victims' expectations as they would be informed from the outset of the modalities of their participation.

6. The rights of victims and the rights of the accused must no longer be perceived as inherently contradictory. Nonetheless, the trial process is intrinsically limited by certain judicial safeguards. Therefore, the Court must encourage resource allocation and stakeholder investment into extra-judicial programmes to benefit the victims whom the limited participatory process is currently failing.

The ICC's victim participation scheme is certainly a step forward for victims of sexual violence, and for victims of international crimes more broadly. However, for the scheme to benefit those it seeks to help, it must be reworked with the focus of acknowledging victims' experiences and listening to their voices - a function of justice that must not be ignored. If the underlying purpose of the victim participation scheme is to, indeed, contribute to restorative justice, meaningful participation is required, and the Court must be creative in addressing these challenges. 